\title{
GOOD WISHES
}

TO The Bookman's Fournal and Print Collector. Under the editorship of Mr. Wilfred Partington this has won the affection of many book lovers during its two years' existence as a weekly, by its lightness of touch, its modernity, and its consistent good feeling in all cases where good feeling is needed. It has now become a two-shilling monthly, and starts with some admirable illustrations of work by Mr. James McBey, and articles by Mr. Shorter on George Meredith, by Professor Saintsbury on Austin Dobson-' the man and his work', by Mr. Drinkwater on 'The World and the Artist', by Mr. Herbert Garland on that most difficult problem Mr. Voynich's cipher manuscript by Roger Bacon (which Professor Newbold is trying so hard to read), and by Mr. Davenport on English gold-tooled Bindings. There are also poems by Mr. De la Mare, and numerous reviews. I feel, a little enviously, it must be nice to be so modern, and hope that all readers of $T$ be Library will join in good wishes to $T$ be Bookman's Fournal, which is winning many new readers to the cause of bibliography.

To The London Mercury. The $L$. $M$. needs no praise, but a word of congratulation may be permitted at the beginning of its third year, and it also deserves our good wishes as a popularizer of bibliography and a discoverer of good work. An editorial note tells us that in its first year it had 'ninety'four different signatures to contributions' and that this number has now been increased by sixty new ones. $T$ be London Mercury not only has monthly 'Bibliographical Notes', but also monthly 'Book-Production Notes', a topic which has not received as much attention from the Biblio- 
graphical Society as it deserves. We have done well in celebrating the fine work of early printers, but we have done very little to encourage fine work among our contemporaries, and Mr. Newdigate's notes should stir us to do more.

To The Print Collector's Quarterly. Nos. 2 and 3 of this contain articles on Jean Duvet by Mr. A. E. Popham; on The Modern Woodcut by Herbert Furst; on etchings of Méryon (by H. J. L. Wright), George Clausen (by Frank Gibson), and Sir J. C. Robinson (by R. L. Allhusen); and on the work of Hendrik, Count Goudt (by H. S. Reitlinger), and Albert Besnard (by Clément Janin). The profusion of illustrations in each number fills me with hopeless admiration.

To The Subject Index to Periodicals, 19I7-1919. Issued by The Library Association. Language and Literature: (i) Classical, Oriental, and Primitive, 2s. 6d.; (ii) Modern European, 5s. Of this I can only say that it raises subjectindexing to a new power by adding, to the vague titles which writers in periodicals so often affect, beautifully concise notes as to what the articles are really about. The work is so good throughout that it must be done by a small army of specialists, and it deserves all possible praise and support

A. W. P. 